\title{
A PIONEER SETTLEMENT IN MADISON COUNTY.
}

BY W. S. WILKINSON.

Early in the spring of 1847 my oldest brother, Alfred, came from Davis county, Iowa, with one horse to Ft. Des Moines, and rented twenty acres of ground of Mr. Lamb, about where the starch factory now stands. He planted it in corn, agreeing to give one-half for rent.

Abont the first of June my father with the rest of the family followed, but being stopped by high water we remained in Marion county for some time, not reaching the neighborhood of the Forks, as the union of the Raccoon and Des Moines rivers was then usually called, until towards fall. We lived that fall and winter on Four Mile creek about six miles northeast of the Forks. During the winter reports came to us that the country up here was a fine place with good soil, nice rolling prairies, plenty of stone, an abundance of fine flowing springs, plenty of good timber along the streams, and that the principal undergrowth was rattle: snakes. On our arrival we found plenty of the "undergrowth."

Early in the spring of $1848 \mathrm{my}$ father and brother, Thomas, came to Madison county to locate a claim, and built a cabin within a few steps of a spring just one and one-half miles north of the center of Scott township. They covered the cabin in the usual way with clapboards and weight poles, but running short of boards they covered a small patch with elm bark. One-half of the floor was laid with puncheon split from linn logs and smoothed with a broad-axe; the other half was laid with bark placed flat on the ground. A stick and mud chimney was built with a stone wall and jambs for a fireplace.

My father and brother then returned and removed the family from Polk county as soon as the stock could live on the grass. We started about the 20th of April, 1848, with 
our cows, sheep, hogs, chickens, a pair of geese and our household goods. We arrived at our new home just after dark on Friday, April 23, 1848. The next day we unloaded our wagon and fixed things for housekeeping, while our stock grazed on the grass. The next day being Sunday we rested and viewed the landscape o'er. On Monday morning we went to work clearing a piece of timber land to plant in corn, our horse team not being able to turn the prairie sod. We put in eight or ten acres of corn, and later planted a good patch of potatoes, cabbage and other vegetables. Truck grew nicely so that in the fall we had a fine supply of vegetables. Our corn when cut up made a fine lot of feed, but the grain was not well matured on account of being planted so late.

After the crops were tended the settlers began to pay some attention to schooling for their children. They built a $\log$ cabin for a schoolhouse just east of the Buffalo mills in what is now Eli Wright's field, and hired James Thornburgh to teach a term of school. He commenced sometime in August and taught six weeks. The fall work coming on he closed the school until winter, but the snow was so deep that winter that the children could not go, so he never finished the term. That was the first school taught in the county. The pupils attending that term, as well as I can remember were: Absalom, Daniel, Thomas, Aaron, Ann and Emeline McKinzie, Louisa, Rebecca and Joseph Thornburgh, James and Ann Crawford, Will and Jack Hart, Henry Evans, Will Butler, Miles Casebier, Thomas, Mar. garet, David and W. S. Wilkinson. I think there were two or three others but I can not recall their names. Of the above only two are living in this county, Henry Evans and myself. Two are living in Kansas, one in Washington, two in Oregon, and one in Rock Island, Ill. A year or so later some school districts were marked off, and the Roger school house in Scott township was built. Mrs. Danforth, mother of Chal and William Danforth, taught the first school there. 
That fall my father and some of the neigbbors went on a bee hunt up the Coon river. They found and cut eighty bee trees, and brought home a fine lot of boney. After straining it they hauled it to St. Joseph, Missouri, and traded it for their winter supply of groceries. Had they not secured their provisions in that way I do not know how they would have got them. They returned on the $2 \mathrm{~d}$ of December, 1848, and the next morning the snow was about four inches deep. It continued to snow till it became a big snow -the deepest I ever saw. It must have been at least three feet on the level, some said it was more. The settlers could not keep the roads broken through that snow, not even to the mill. They kept tracks broken from house to house so they could go on horseback, and their milling was done in that way.

During the summer of 1848 Hart \& Hinkley built a little grist mill on the site where the Buffalo mill afterwards stood. They started sometime in the fall. It was a small affair, but. it answered the settlers' purpose well that winter of the deep snow. I do not know how they could have got along without the mill. They could grind nothing but corn, in fact there was nothing else to grind that winter. The next season I think they had some buckwhent and possibly a very little wheat to grind. The millers got some kind of a screen to sift their buckwheat. They called it a "sarse." I do not know what it was like, probably the real name was sarcenet, a hand-bolt made of sarcenet silk. Of course, we did not get good flour, but it was a change from corn bread.

I think the first Sunday school in the county was organized the summer of 1848 at the house of Levi Bishop in Scott township. Sam Fleener was superintendent and Mrs. Bishop teacher. They did not confine their instruction to the scriptures alone, but taught the little folks their letters, spelling and reading. The books used were the spelling book and testament.

The first bridge in this county was built in the fall and voc. VI-?9. 
winter of $1854-55$ across Middle river, where the Indianola and Winterset road crossed that stream in Scott township, now known as the Holliwell bridge. - Madison county paid John McCartney $\$ 500$ for building it. The bridge was a forty-foot span with a framed approach at each end. It was a frame bridge with double bents at each end of the span twenty-two feet high. The timbers of this bridge were hewn sixteen inches square. The stringers of the main span were forty-four feet long to lap at the ends on the bents. The framed approaches at each end were twenty feet long. The bridge was finished early in the spring of 1855 .

The prairie in this county was like most of the prairies of the State, they were beautiful of course, but were thickly covered with the bones and horns of the buffalo, elk, deer and other animals that had been slain for their flesh and pelts. In early spring you could not go many rods in any direction on Hoosier prairie without coming onto the whitened bones of some of these animals. When the prairies were covered with fresh green grass they were beatiful, but the time of their greatest beauty was perhaps in the month of June, when the lily, the sweet-william, and the prairie-rose were in full bloom; around the edges of the timber the lady-slipper and wild tiger-lily grew, but they are all gone. Nor were the woods without their enchantment-those beautiful sugar-maples, those splendid black walnuts, those noble cottonwoods, that used to line our streams, but they are gone-gone never to return. Now I am an old man, my eye-sight is growing dim, I would like once more to see the green prairies with their beautiful flowers, the trees standing, the springs flowing as they did in the days of my youth.

In an early day the work was done in a primitive way. The cooking was done by the fireplace, as they had no stoves. The bread was baked in tine skillet which was first heated, the lid which covered it was also heated, then the skillet was placed upon the coals on the hearth, the dough 
put in and the hot lid placed over it; coals were also put on the lid to keep up the heat. This skillet was shallow and used for baking biscuits, etc. The Dutch oven was used for baking light bread, pies, and pones. The oven was several inches deeper than the skillet but used in the same way with the lid as the skillet. The coffee was boiled in a pot over the coals drawn out on the hearth. The pots were boiled over the fire. Many fireplaces had a crane placed in the jamb to hang the pots on, and made adjustable to suit circumstances. Some used the Johnny-cake board upon which the most delicious corn bread was made. Meat was sometimes hung before the fire and roasted, which was considered very good.

The clothing was made in the home. The old settlers had their flock of sheep from which to obtain the wool for their winter clothing. The wool was washed and picked to clean out all burrs, then carded by hand and spun into yarn, and woven into jeans, linseys and flannels. The summer wear was made from flax. The flax was sown early in the spring, and when ripe it was pulled, bound in bundles, and shocked to dry. The seed was whipped off and then put in water to rot the stem so it would separate from the lint, then spread out to dry. Afterwards it was broken on a flax brake and swingled with a wooden swingling knife, the flax being held over the top of a swingling board with one hand and the knife wielded with the other. Then it was drawn through the hackle to take out the shives and tow. The best of the tow was used to make coarse garments of which I shall speak later. After the material was prepared it was spun into yarn on hand spinning-wheels and dyed, if necessary, then taken to the family loom.

The loom was made the same as the carpet looms that we sometimes see at the present time, but with different reeds, heddles and shuttles. In fact the gearing was arranged for each kind of cloth to be made. After the threads were spun they were run into hanks on winding blades and 
then onto large spools and from that onto the warping bars into warps. The warp was then run onto the large beam of the loom. One end of the warp was then drawn through the heddles and on through the reeds in the batten to the front of the loom, then tied on a bar and then brought over the breast beam down to cloth beam. The filling was run on quills and placed in the shuttle which was passed through the warp. This was then divided by the heddles by tramping of the treadles, and this filling was beaten up with the batten which held the reed or stay, as it was also called. The best of the tow was often used to make coarse garments for the little boys. There was the tow pants and the tow shirt. The long shirt was quite a novelty; being worn without pants, it made it cool in warm weather.

The farming tools of an early day were very simple. The first plow I used was a wooden mould board plow with a metal lay and bar welded together at the point. The diamond plow came into use about that time, but we used the wooden mould board several years. Our harrows, hand rakes and pitchforks were made of wood.

The old settlers worked hard and lived plainly and were usually healthy. If a man got sick he got well again. That was before the doctors came. Now sometimes a man gets well in spite of two or three doctors.

The early settlers made their ropes out of flax or bemp. Hemp is probably the best for ropes, but both were used. After the twine was spun it was stretched in a home-made rope-walk and twisted into a rope. This home-made ropewalk was made on the same principle as the factories we have today. They ran the twist into the rope just the same as the ropes we get today. A man can make a rope-walk in half a day.

Early settlements were made along Clanton creekRhynos and Johnstons among them, who went to raising cattle, and became quite successful, but they could raise cattle faster than they could subdue the prairie sod, and 
raise grain. During some of those hard winters in an early day they sometimes lost pretty heavily in cattle. When an animal died its hide was taken off to help along the hide trade. They frequently joked one another about their misfortunes. One hard winter about ',55 or ' 56 when they were losing heavily, a story was told on Jeff Rhyno that he discharged a man because be could not skin the cattle as fast as they died.

As to amusements there was not so great a variety as at the present day, but they were engaged in with as much interest as today. During the fall and winter the young people would get together evenings, first at one house and then at another to discuss such questions as had been previously arranged. There were usually some of the older men present to act as judges and give encouragement while the young folks engaged in the discussions. At other times they would have a spelling match. There was always perfect order at these meetings. Later, towards spring, there would come the rail-splitting and log-rollings. At these the young folks usually had a party at night. Later came the corn planting which was all done by hand. When one man had a piece of ground ready to plant, his neighbors would turn in and help him plant it. After that came the flax pullings and harvest, and later on the corn cutting. The old settlers were very sociable, and those meetings were prized for the good feeling and fellowship they created. There were the house-raisings at all times of the year, and they were as much of a picnic as anything. Men used often to go ten miles to a raising.

How courting was done in an early day might come under this head. According to one writer the process has not materially changed for several hundred years, but the conveniences have changed. In those days they had no parlors or drawing rooms to sit in, since the whole house was in one room, a log cabin 16 or 18 feet square. In one end was a large fireplace that would take in a stick four or five 
feet long, and in the corners on each side was the place where the courting was usually done. Across the other end of the house stood two high old fashioned bedsteads, one for "pap" and mother, and the other for our big sisters, and there were two trundle-beds which were slipped under the beds in day time and drawn out at night. These were for the little folks to sleep in, hence they were called trundlebed stock. We larger boys usually slept in the loft in the winter. The loft was covered with loose clapboards. On Sunday evenings when our sisters had company we would slip over to a crack and peep down. That is the way the boys saw it. When the young couple decided to get married and the match was opposed by the parents they would run off to Missouri and find a minister to tie the knot so' well that it would never come undone. The girl would then write her parents that she would return if her husband would be welcome in the home. In an early day getting married was somewhat different from today in the matter of expense. If a young man had a suit of blue jeans with a row of brass buttons down each side of his coat front, that was all that. was required. If the girl had a new calico dress that was all that was necessary. Again, it was not necessary to pay the preacher five or ten dollars for tying the knot. That duty was performed free of charge, the minister considering himself ahead by the good dinner that was served on those occasions.-Winterset Madisonian, May 19, 1904.

The Season.-We have had an unusually cold and wet spring. The earth has been so completely saturated by the constant rains that the progress of the farmer, miner and smelter has been much retarded. For a week past, however, the weather has been delightful; every kind of business has taken a fresh start, and vegetation appears to be making up for lost time.-DuBuque Visitor, May 11, 1836. 
Copyright of Annals of Iowa is the property of State of Iowa, by \& through the State Historical Society of Iowa and its content may not be copied or emailed to multiple sites or posted to a listserv without the copyright holder's express written permission. However, users may print, download, or email articles for individual use. 